\title{
"FACTORS AFFECTING THE PRODUCTIVITY OF AREA WORKSHOP ON A HONDA DEALERSHIP IN QUINTANA ROO, MEXICO: EMPIRICAL ANALYSIS"
}

\author{
Norma Yadira Ramos Aranda, M.A. \\ Universidad Autónoma de Ciudad Juárez, México \\ Francisco Javier Güemez, Ricalde, PhD, \\ Universidad de Quintana Roo, México \\ Agustín Vilchis Vidal, PhD, \\ Universidad Autónoma de Ciudad Juárez, México
}

Doi: 10.19044/elp.v2no1a2 URL:http://dx.doi.org/10.19044/elp.v2no1a2

\begin{abstract}
This study seeks to establish perceptions of factors affecting the productivity of the workshop in a Honda automobile dealership in Playa del Carmen. The research is exploratory type, using a mixed method, previously validated, with open questions and Likert scale for all staff questionnaire service area; and a semi structured interview with the branch manager. In the interpretation of the data SPSS version 18 was used, the Pearson correlation coefficient for hypothesis testing was used, selecting the highest correlations of 1.00 and a lower estimated error to 0.05 and significance level of 0.95 , based on the method of analysis of internal factors. Derived from the results, highlights the correlation between the independent variables and work against Capital Productivity was 0,248 and 0.25 respectively, which is considered low. In contrast, the administrative management had an association of 0.76 which means a high ratio. Productivity in the Honda dealership in Playa del Carmen study, may explain most of the time the data in terms of dissimilarities by factors and analyzed on an individual basis: Administrative Management, capital and technology and to a lesser extent differences in quantity and quality of manpower. Globally the mode that includes the analysis of all the responses of the 4 factors optimizes the analysis and validates the model developed for obtaining answers.
\end{abstract}

Keywords: Dealership, productivity, work, capital, management 


\section{Introduction}

At the global level, the importance of the automotive industry in national economies and its role as a booster for the development cannot be overemphasized. Other high-value-added sectors, have caused various countries have as one of its main objectives the development and/or strengthening of this industry. Mexico is no exception, as the automotive industry has represented a strategic sector for its development. Its participation in exports places it as the most important industry, surpassing even the oil sector. In 2011, the automotive industry exported $22.5 \%$ of the value of total exports Secretariat of Economy (2012).

The production of light vehicles continues to exceed historical levels, both for the month of September as the cumulative figure for the first eight months of the year. In August 2014271.406 units were manufactured, realizing a growth of $4.7 \%$ compared to the eighth month of 2013 . In both the accumulated record 2,128.634 vehicles were manufactured in our country, $7.2 \%$ higher than what occurred in the eight months of last year. Of the total produced, $83 \%$ corresponds to units designed for the external market, and the remaining $17 \%$ corresponds to units for the domestic market.

Based on the publication of Organization Internationale des Constructeurs d'Automobiles (OICA) in 2013, Mexico was placed as the eighth largest producer of vehicles at the global level and Brazil as the seventh. The production in Brazil ranged from 300 thousand units produced per month, while in Mexico ranged from 250 thousand units manufactured. However, during the first eight months of 2014, Mexico produced $8.7 \%$ more light vehicles than those produced in Brazil. In August this year, the production of light vehicles in Brazil fell to $17.9 \%$ over the same period of 2013, in Argentina the decrease was $25 \%$, while Mexico grew by $7.2 \%$, passing the seventh place as a manufacturer of light vehicles in the world between January to August 2014. It should be noted that recently announced three new auto plants in Mexico, could represent an additional production capacity of around 600 thousand units by Mexican Association of the Automotive Industry (2014).

In 2014, the Mexican automotive industry ranked number 7 in the production of light vehicles, making it be among the main global producers. The January-August 2014 accumulated record level was achieved compared to the exports of $1,732,262$ units and a growth of $9.6 \%$ over the same period of 2013.

According to the report of Ward's Automotive, in the U.S., 11, 132.209 light vehicles were marketed in the first eight months of 2014, 5\% higher than what was marketed the previous year same period. In the accumulated, the Mexican vehicles accounted for $11.1 \%$ of the total light 
vehicles sold in the United States, that is 1, 232.457 light vehicles. Keeping our country as the second vehicle supplier, after Canada, the countries that provide to the United States showed positive growth rates, with Mexico showing the highest rate, of $17.6 \%$, compared to the cumulative JanuaryAugust 2013 by Mexican Association of the Automotive Industry (2014).

In this context, the objective of this work is to evaluate the perception of the factors in the organizations that influence the productivity such as; research, development, capacity, government, equipment, costs, ethics, workers, union, motivation, labor, capital, management, among others. Of which the last three were with greater weight with $(9,14$ and 14) votes in favor of a total of 21 authors who have studied the productivity in the companies. If these are properly identified, there is a greater chance of success when you diagnose the condition of the productivity of a recognized automotive concessionaire and on all the actions and techniques that should be applied for the improvement of the same.

The rationale in this topic is to ensure the future of a concessionaire, the area of post-sale service (workshop) offers services in matters of maintenance, repairs and diagnostics to the vehicles, which in turn have approximately 15,000 parts. This is divided among seven complex systems that are: engine, train travel, rims-tires-brakes, suspension, steering, electrical system and bodywork and chassis. The information provided by the concessionaire automotive, indicates that $80 \%$ of the return of the vehicles to the area of post sale is to make some type of maintenance, to continue the repairs and finally the diagnostics, both are equivalent to the 20\% remaining Honda Playa del Carmen (2014). Based on the above circumstances, it has prompted the study to "Perform an empirical analysis of the factors that affect productivity in the workshop area of a concessionaire automotive".

The article chronologically develops the analysis from the theoretical review, to describe the method used in the data collection. Describes the results of the analysis through the application of software and is concretized in the final part the conclusions deriving from the initial hypothesis and the objectives to be achieved in the research.

\section{Review of the literature}

The conductor of the word productivity is between a relationship of means of production and the results obtained, (Quesney, 1766). It means the ability to develop more products in the same way Littre, (1883) is conceptualized as the faculty of produce, i.e. the ability of an organization in order to generate more finished products. Early, (1905) says that it is the relationship between the production and the means employed to achieve this, while the Organization for European Economic Cooperation (OEEC, 1950) 
mentions that it is the quotient obtained by dividing the production and one of the factors of production, in terms of David, (1955) is the change in the product obtained by resources spent, with regard to Fabricant, (1962) there is always a relationship between the production and the inputs, and same for Kendrich and Creamer, (1965) are functional definitions for the partial productivity factor of total, for Siegel, (1976) is represented by a family of reasons between production and the inputs and finally Sumanth, (1979) says that the total productivity; it is the reason for production inputs between the tangible, the above mentioned it is submitted by the author Sumanth, (1990).

In terms of the variables to measure that are (labor, capital and administration), we can see the following input from a number of renowned authors. Bruce, (2006), and his colleagues came to the conclusion that the increase in productivity due to social factors such as the morality of the employees, the existence of satisfactory interrelationships between members of a working group "sense of belonging" and the effectiveness of the administration, a type of administration capable of understanding human behavior, especially the group behavior, through interpersonal skills such as, motivation, counseling, guidance, and communication. This phenomenon, product on the fact that put attention on individuals, is known as "Effect Hawthorne".

Brown, Lauder and David, (2011) developed a system of rational organization of labor widely exposed in his book Principles of Scientific Management (1911), in an integral approach which was then known as "taylorism". It is based on the application of scientific methods of guidance and positivist mechanistic to the study of the relationship between the worker and the modern techniques of industrial production, in order to maximize the efficiency of labor, machinery and tools, through the systematic division of the tasks, the rational organization of labor in their sequences and processes, and timing of operations, more a system of motivation through the payment of premiums to the performance by eliminating all improvisation in industrial activity.

The general reasons why it is important to measure the productivity according to Pritchard, (1973) are; facilitates communication among the members of the organization, helps to evaluate the progress toward the improvement of productivity, facilitates making changes after a certain period, reveals potential problems and identifies opportunities for improvement, it is a form of feedback, is a source of motivation, and help establish priorities, identifies the problems before they become serious, aid to the decision-making, provides the statistical analysis and mathematical and aid to the long-term planning process. In addition to the measurement of productivity in different periods of time, you can compare the results to 
know the behavior of team, performance the staff, and find areas of opportunity to improve.

The model of Craig and Harris, (1973) said that if you increase the productivity of labor; improving the quality of the raw material, does not exceed the savings achieved by reduction of hours and physical inputs are converted into money, paid by the inputs provided.

For its part, (Novit, 1979 ;Torres, 1997), noted that the factors that cause productivity include; assets, working methods, the quality of the raw materials, the availability of transportation and the labor force, while the model for improvement in employee productivity in Japan by industrial enterprises and trade pointed out three factors as the most important: the investment in capital, human resource development and the implementation of the administrative management in organizations (Asomoza, 1985).

According to Adam, and Hershauer, (1981), productivity is a term that describes how the conversion of inputs into outputs. Also, defined as the ratio of the four major resource inputs of an organization.

$\frac{\text { Productivity }=\quad \text { Products }}{\text { Labor Capital + Materials + Energy. }}$

For Ghobadian, (1990), the capital is composed of the following components: Reserve of fixed capital (gross or net), working capital, land and labor (hours worked, number of employees, cost of labor, quantity, price, time, direct and indirect labor, materials and supplies. Schroeder, (1991) says that productivity is the relationship between inputs and outputs of a productive system.

Sumanth, (1993) suggests that if the countries have to improve their productivity levels and growth of their tasks, the fight must begin to an enterprise level. With the purpose to be effective, it must be formal and be based on strategies that revolve around a common pattern, which today is known as "the cycle of productivity" that propose the following these steps:

Cycle of productivity. (Measurement of productivity, productivity Assessment, Planning of productivity and improving the productivity).

For its part, Kast, (1993) considers that the administration has a vital role in improving the productivity, given that it acquires resources and investment decisions that affect the level of technology of an organization and individuals are the ones who carry out the tasks assigned to each level, from the hierarchy more high, up to the lowest. The improvement of the productivity requires an administration directly involved in the operational level. The same author, also said that "the productivity is influenced substantially by the motivation and the dedication of the people". 
According to Everett, (1994), the worker productivity is the key to the economic viability and the accumulation of wealth, increases with the specialization and the design of the post, it is incremental when the working class works best, progress is through investments in capital. Then, the productivity of the staff is remarkable through the indexes of management, through a director capable and motivating, that make the members a real team, resulting in a productivity ascending.

Productivity according to Bain, (1997) is not only a measure of production or less, the amount of property that has been manufactured. It is a measure of how well that have been combined and used the resources to meet the specific objectives desirable.

The first step in the improvement of the productivity according to Prokopenko, (1987) consists of identifying the problems that arise in these groups of factors and distinguish between the factors that are controllable. The factors for a company that are external and non-controllable, may be internal to another institution, such as for example, the institutions of public administration, which can improve the conditions of the companies through fiscal policy, labor legislation, access to natural resources, social infrastructure, etc.

It is very difficult to measure the productivity of the office work. Prokopenko, (1987) suggests the method of working time, starting from the principle that it is constant to perform certain basic activities, and the sampling method, by means of percentages of time used by each staff member in performing tasks. Continued with the author, proposes to divide the number of hours worked by the number of available hours to reach an effectiveness percentage, in such a manner that an increase in the relationship means self-improvement. By way of conclusion, this researcher suggests that the productivity can also be seen as a synonym for innovation and technological development, due to the technological change being incorporated in different periods to the production processes, enhances productivity with the knowledge of new manufacturing techniques, process automation, invention of new materials of higher quality and lower price, etc.

Productivity for Heizer and Render, (2009) is the result of dividing the outputs (goods and services) between one or more entries (such as labor, capital or management). These three factors are critical to increase the productivity. Represent the major areas in which administrators can act to improve the productivity, below are described in short form:

Labor (Labor). The improvement in the contribution of labor productivity is the result of a labor force healthier, better educated and more motivated.

Capital. Capital investment is often needed, but it is rarely a sufficient ingredient in the battle to increase productivity. 
Administration. The administration is a factor in production and an economic resource. The administration is responsible for ensuring that labor and capital are used effectively to increase productivity. The administration is responsible for more than half of the annual increase in productivity. This increase includes the improvements made through the application of technology and the use of knowledge. The education and training required represent important components of high cost are the responsibility of the operations managers when they build organizations and labor forces.

The more effective utilization of capital also contributes to the productivity. The administrator, as a catalyst for productivity, it is also responsible for selecting the best new capital investment, as well as improve the productivity of existing investments.

The American Management Association (Torres, 1997), in a survey carried out among six thousand executives of large corporations in the United States, to identify the factors that influence the productivity, defining the three most important areas; technology was marked by the $35 \%$ of managers, the $27 \%$ corresponded to the investment of capital and more than $20 \%$ indicated that the decisive factor was the administration.

Porter, (2000), suggests that competitiveness raises the productivity so that companies used their factors to produce valuable products and services. It may be inferred from the above-mentioned approach, that the only meaningful concept of competitiveness is the productivity, as the only tool to compete in more advanced sectors.

At present, the strategy and technological innovation are key elements for the competitiveness of the company and represent a significant determinant of the economic growth, innovation makes it possible for the organization to respond to market changes and, in this way, to achieve sustainable competitive advantages over time.

The input-output model of the company Leontief, (1973), based its importance in the relationship of the production function with the inputs, considering the productivity as a result of this relationship, that has to generate income that facilitate the recovery of input costs. When it focuses on the productivity exclusively the labor factor is missed. Therefore the model treats all of the elements or inputs interrelated, which provides a more integrated performance or productivity.

Sustermeister, (1976) presented a model on the productivity of the worker which is based on measurement of the performance of the worker and their impact on productivity. For this brings together all the items into two groups; technological development and human motivation.

The first varies with the type of industry and manufacturing system, and the second is due to personnel policies or not motivating the individual in his personality and ability intrinsic. 
The motivational model Lawler, (1968) says that for the improvement of the productivity should be considered the relations existing between the preset psychological perceptions of equity, satisfaction and ability to affect the effort, with the probabilities of the effort for the performance. Constitute a normative model of individual performance.

\section{Methodology}

Methodological strategy for perception of productivity factors Types of research.

Scientific research, in a general way, to the activity that allows us to obtain scientific knowledge, i.e. knowledge that is sought to be objective, systematic, clear, organized and verifiable. The subject of this activity is commonly called researcher, and in charge runs the effort to develop the various tasks required to achieve a new knowledge. The objects of study are the infinite topics and problems that demand the attention of the scientific, often grouped and classified according to the various sciences or existing specialties (Sabino, 1992).

Research helps us to improve the study because it allows us to establish contact with reality so that we have better knowledge of the phenomenon understudy. The purpose of this is to formulate new theories or modify existing ones, to increase the knowledge, this is the way to reach to develop theories. Research activity is effectively leads through a series of elements that make it accessible, the object to the knowledge and whose wise choice and application is going to depend heavily on the success of research work. Scientific research is the activity of search that is characterized by being thoughtful, systematic and methodical and aims to obtain knowledge and solve scientific problems, philosophical or empirical-technicalities, and develops through a process. Scientific research is the method which indicates the path that has to travel in such an inquiry and the techniques require the way to travel (Tamayo, 2003).

From a structural point of view we recognize four elements present in any investigation; subject, object, and middle and end (Tamayo, 2003).

It is understood by subject that develops the activity, the investigator;

By object, which investigates, that is, the subject or the subject;

By means, what is required to carry out the activity, i.e., the set of appropriate methods and techniques?

Finally, the aim, the purposes of the activity of search, which lies in the solution of a problem detected.

It should be noted that in reality, the research cannot be classified exclusively to one of the types that will be brought, but which is generally in any investigation pursues a purpose pointed out, is looking for a certain level of knowledge and is based on a particular strategy or combined (Tamayo, 2003). 
For the purpose or purposes persecuted: basic or applied.

Basic Research: Also receives the name of pure research, theoretical or dogmatic. It is characterized because part of a theoretical framework and remains in the; the purpose is to formulate new theories or modify existing ones, to increase the scientific or philosophical knowledge, but without contrasted with no practical aspect (Tamayo, 2003).

Applied Research: This type of research also receives the name of practice or empirical. It is characterized because it looks for the application or use of the knowledge that is acquired. Applied research is closely linked with the basic research, because it depends on the results and progress of the latter; this is clarified if we realize that all applied research requires a theoretical framework. However, in an empirical investigation, what is of interest to the researcher, primarily, are the practical consequences. If a research involves problems both theoretical and practical, receives the name of joint. In reality, a large number of research depends on the nature of basic research and applied (Tamayo, 2003).

For the purposes of this research we can say is mixed because they apply the knowledge acquired from a theoretical framework.

By the class of means used to obtain data: documentary, or experimental field.

Documentary research: This type of research is being performed, as its name indicates, relying on sources of documentary, this is, in documents of any kind. As subtypes of this research work, we found the bibliographic research, the periodical and archives; the first is based on the query of books, the second in articles or essays to magazines and newspapers, and the third in documents that are found in the files, such as letters, offices, circulars, dossiers, etc. (Tamayo, 2003).

Field Research: This type of research was based on information coming from inter, interviews, questionnaires, surveys and observations. As it is compatible develop this type of research along with the documentary research, it is recommended that you first consult the sources of the documentary, in order to avoid a duplication of work (Tamayo, 2003).

Experimental Research: Receives this name that gets its information from the intentional activity carried out by the researcher and is aimed at changing the reality with the purpose of creating the phenomenon itself that investigates, and thus be able to observe it (Tamayo, 2003).

In this research, it was to use both ways documentary since it went to books, journal articles, review in own documents of the company (procedural manuals, control sheets), and field (questionnaire applied to a free and personal interview semi addressed to the service manager and observation).

By the level of knowledge that are acquired: Exploratory, descriptive or explanatory. 
Exploratory Research: The research that is performed with the purpose of highlighting the fundamental aspects of a particular problem and find the suitable procedures to develop a subsequent investigation. It is useful to develop this type of research because, in the count with their results, simplifies open lines of research and proceed to its consistent testing (Tamayo, 2003).

Descriptive research: This type of research uses the method of analysis, achieved, characterized an object of study or a specific situation, determine their characteristics and properties. Combined with certain criteria of classification is used for sorting, grouping or systematize the objects involved in investigative work. Like the research that we have described above, can serve as a basis for investigations that require a higher level of depth (Tamayo, 2003).

Explanatory Research: This type of research requires a combination of analytical and synthetic methods, in combination with the deductive and inductive, it seeks to respond or to give an account of the because of the object being investigated (Tamayo, 2003).

In this sense, we can conclude that in this study, the research is explanatory type, since it was the combination of the synthetic and analytical methods, it is a matter of responding to give an account of a phenomenon because the object that is investigated is explanatory and is given by fact that makes use of the other investigations (descriptive and exploratory) since reaching the explanatory, must necessarily have passed by the previous.

When it is going to solve a problem in any scientific way, is very desirable to have a detailed knowledge of the possible types of research that you can follow. This knowledge makes it possible to avoid mistakes in the choice of the appropriate method for a specific procedure. It should be noted that the types of research are hardly pure; they are usually combined and obey systematically to the application of research. Traditionally there are three types of research (Tamayo, 2003).

Historic (describes what it was): This is the past experience; applies not only to history but also on the sciences of nature, the law, medicine or any other scientific discipline. At present, the historical research is presented as a critical search for the truth behind the events of past (Tamayo, 2003).

Descriptive (interprets what is): Includes a description, registration, analysis and interpretation of the current nature, and the composition or processes of the phenomena. The focus is on dominant or conclusions on how a person, group or thing driving or operating in the present. Descriptive research works on realities of facts, and its main feature is the presented us with a correct interpretation (Tamayo, 2003).

Experimental (describes what will): Occurs through the manipulation of an experimental variable not checked under rigorously controlled 
conditions, in order to describe in detail how or for what cause occurs a particular situation or event. The experiment is a situation caused by the researcher to enter certain variables manipulated by the study, to control the increase or decrease of these variables and their effect on the observed behaviors. The task of the investigator is to handle deliberately experimental variable and then look at what happens in controlled conditions (Tamayo, 2003). (correlation)

Classification of the variables by their position in a hypothesis

Rojas, (2004) says that the variables can be classified into: Independent, dependent and inter-current or responders.

The independent variable should be understood, the element (phenomenon, situation) that explains, condition or determines the presence of another; the dependent variable can be defined as the element (phenomenon, situation) explained or that is a function of another, and the variable or inter-current responder is the element that may be present in a relationship between the independent variable and the dependent, i.e. influences the appearance of another element, but only in an indirect way.

Located in a schema, the three types of variables would be thus: Independent Variable Dependent Variable

Intercurrent Variable or responder

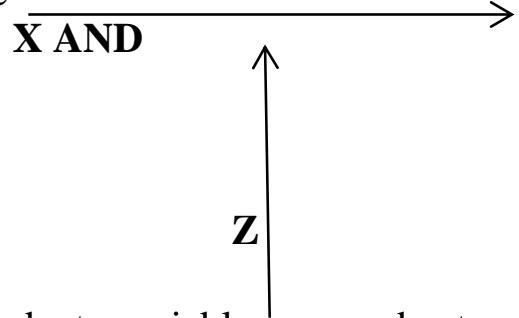

In the present study by independent variable are understood as the (labor, capital and management), in the same manner the dependent variable is represented by the productivity and finally the variable or intercurrent responder includes both (the organizational culture, geographical position of the concessionaires, organizational climate, etc.), which they will not be the object of investigation, only will be taken into account the variable dependent and independent variables.

\section{Definition operationalization of variables}

After you have identified and defined the variables, the next step which is the operationalization of variables for (Sabino, 1992), the operationalization of the variables defined as the process of bringing a variable from an abstract level to a more concrete level, its basic function is to specify the maximum meanings given to a variable in a particular study, we must also understand the process as a way to explain how to measure the variables that have been selected, 
Similarly, Hernandez, (2000), defines the operationalization of variables as a process, presented academically in a box designed to such effect, in which are presented and defined the variables that the researcher has determined within the problem that was raised. In this table, relate to the overall objective of the investigation, it defines each of the variables in the context of the research, are also placed the dimensions of each one and their indicators (Hidalgo, Hurtado, and Santos, 2014).

\section{The operationalization of variables}

It is a process that starts with the definition of variables as a function of measurable factors strictly to those who are called indicators.

The process forces to perform a conceptual definition of the variables to break the vague concept that it encompasses and give you specific direction within the research, then as a function of this is processed to perform the operational definition of the same to identify the indicators that will allow you to perform your measurement and quantitative empirical form, as well as qualitatively if appropriate (Ferrer, 2010).

Operationalization of variables

\begin{tabular}{|c|c|c|c|c|c|}
\hline $\begin{array}{c}\text { Variable } \\
\text { Definition and } \\
\text { Conceptual }\end{array}$ & $\begin{array}{c}\text { Operational } \\
\text { Definition }\end{array}$ & $\begin{array}{c}\text { Dimension } \\
\mathbf{s}\end{array}$ & Indicators & Questions & $\begin{array}{c}\text { Techniqu } \\
\text { es }\end{array}$ \\
\hline $\begin{array}{l}\text { Productivity: For } \\
\text { (Heizer and } \\
\text { render, 1996) is } \\
\text { the result of } \\
\text { dividing the } \\
\text { outputs (goods and } \\
\text { services) between } \\
\text { one or more } \\
\text { entries (such as } \\
\text { labor, capital or } \\
\text { management). }\end{array}$ & $\begin{array}{l}\text { Productivity } \\
\text { can be } \\
\text { achieved } \\
\text { through a } \\
\text { reduction in } \\
\text { the input } \\
\text { while the } \\
\text { output } \\
\text { remains } \\
\text { constant, or } \\
\text { an increase in } \\
\text { the output } \\
\text { while the } \\
\text { entry remains } \\
\text { constant. }\end{array}$ & $\begin{array}{l}\text { 1. Entries. } \\
\text { 2. Outputs. } \\
\text { 3. Labor. } \\
\text { 4. Capital. } \\
5 . \\
\text { Administra } \\
\text { tion. }\end{array}$ & $\begin{array}{c}\text { Number } \\
\text { of diagnos } \\
\text { es. } \\
\text { Number of } \\
\text { repairs } \\
\text { performed. } \\
\text { Number } \\
\text { of mainten } \\
\text { ance made. } \\
\text { Entries of } \\
\text { vehicles in } \\
\text { the month } \\
\text { of April } \\
2014 . \\
\text { Outputs of } \\
\text { vehicles in } \\
\text { the month } \\
\text { of April } \\
2014 .\end{array}$ & $\begin{array}{c}\text { Total of } \\
\text { entries of } \\
\text { car repair, } \\
\text { diagnostics, } \\
\text { maintenanc } \\
\text { e of } 5,10 \\
\text { and } 20 \\
\text { thousand } \\
\text { kilometers, } \\
\text { in the } \\
\text { month of } \\
\text { April of the } \\
\text { year } 2014 ?\end{array}$ & $\begin{array}{l}\text { Questionn } \\
\text { aire, } \\
\text { Likert } \\
\text { Scale. }\end{array}$ \\
\hline
\end{tabular}




\begin{tabular}{|c|c|c|c|c|c|}
\hline $\begin{array}{l}\text { Labor: In the case } \\
\text { of this study } \\
\text { measures the } \\
\text { contribution of } \\
\text { labor to the } \\
\text { volume of } \\
\text { production. } \\
\text { Includes: number } \\
\text { of technicians, } \\
\text { advisors, and other } \\
\text { personnel involved } \\
\text { in the conduct of } \\
\text { the diagnostics, } \\
\text { repairs and } \\
\text { maintenance. }\end{array}$ & $\begin{array}{c}\text { For } \\
\text { (Heizer and } \\
\text { render, 1996). } \\
\text { The } \\
\text { improvement } \\
\text { in the } \\
\text { contribution } \\
\text { of labor } \\
\text { productivity } \\
\text { is the result of } \\
\text { a labor force } \\
\text { healthier, } \\
\text { better } \\
\text { educated and } \\
\text { more } \\
\text { motivated. }\end{array}$ & $\begin{array}{c}\text { 1. Basic } \\
\text { education } \\
\text { appropriate } \\
\text { for an } \\
\text { effective } \\
\text { work } \\
\text { force. } \\
\text { 2. Actual } \\
\text { work time. } \\
3 . \\
\text { Complianc } \\
\text { e with the } \\
\text { training } \\
\text { and } \\
\text { developme } \\
\text { nt plan. } \\
4 . \text { Reality } \\
\text { in the use } \\
\text { of the } \\
\text { facilities. } \\
\text { 5. Number } \\
\text { of } \\
\text { technicians } \\
\text {. } \\
\text { 6. Number } \\
\text { of } \\
\text { advisers. }\end{array}$ & $\begin{array}{l}\text { Total labor } \\
\text { used for } \\
\text { the } \\
\text { realization } \\
\text { of a } \\
\text { diagnosis. } \\
\text { Total labor } \\
\text { used to } \\
\text { perform a } \\
\text { repair. } \\
\text { Total labor } \\
\text { used for } \\
\text { the } \\
\text { realization } \\
\text { of a } \\
\text { maintenan } \\
\text { ce. }\end{array}$ & $\begin{array}{c}\text { Do you } \\
\text { think that } \\
\text { the greater } \\
\text { the } \\
\text { competitio } \\
\text { n of labor } \\
\text { improves } \\
\text { the } \\
\text { productivit } \\
\text { y of the } \\
\text { concession } \\
\text { aire? }\end{array}$ & $\begin{array}{c}\text { Questionn } \\
\text { aire, } \\
\text { Likert } \\
\text { Scale. }\end{array}$ \\
\hline $\begin{array}{l}\text { Capital: For } \\
\text { (Ghobadian, } \\
\text { 1990). The capital } \\
\text { factor includes } \\
\text { machinery, } \\
\text { equipment, land, } \\
\text { buildings, } \\
\text { buildings, } \\
\text { facilities, transport } \\
\text { and tools. } \\
\text { Which with used } \\
\text { for the realization } \\
\text { of the diagnostics, } \\
\text { repairs and } \\
\text { maintenance. }\end{array}$ & $\begin{array}{l}\text { They are the } \\
\text { resources } \\
\text { which the } \\
\text { company } \\
\text { account. } \\
\text { Measures the } \\
\text { productivity } \\
\text { of the assets } \\
\text { of the } \\
\text { company. }\end{array}$ & $\begin{array}{l}\text { 1. Invested } \\
\text { Capital } \\
2 . \text { Wages } \\
3 . \\
\text { Effectiven } \\
\text { ess in the } \\
\text { use of the } \\
\text { facilities. } \\
4 . \\
\text { Efficiency } \\
\text { in the use } \\
\text { of } \\
\text { resources. } \\
5 . \\
\text { Expansion } \\
\text { capability. } \\
6 . \text { Number } \\
\text { of machine } \\
\text { ry with } \\
\text { that } \\
\text { account. } \\
7 . \text { Number } \\
\text { of ramps. }\end{array}$ & $\begin{array}{c}\text { An } \\
\text { approxima } \\
\text { tion of the } \\
\text { capital } \\
\text { invested in } \\
\text { the } \\
\text { workshop } \\
\text { area. } \\
\text { Hourly } \\
\text { rate, in } \\
\text { issues of } \\
\text { diagnostics } \\
\text {, repairs } \\
\text { and } \\
\text { maintenan } \\
\text { ce. } \\
\text { Considere } \\
\text { d an } \\
\text { expansion } \\
\text { of } \\
\text { facilities in } \\
\text { the future. } \\
\text { How many }\end{array}$ & $\begin{array}{c}\text { Do you } \\
\text { consider } \\
\text { that in the } \\
\text { absence of } \\
\text { capital is } \\
\text { significantl } \\
y \\
\text { diminishes } \\
\text { the } \\
\text { productivit } \\
y ?\end{array}$ & $\begin{array}{c}\text { Questionn } \\
\text { aire, } \\
\text { Likert } \\
\text { Scale. }\end{array}$ \\
\hline
\end{tabular}




\begin{tabular}{|c|c|c|c|c|c|}
\hline & & $\begin{array}{c}\text { 8. Tools } \\
\text { used. } \\
\text { 9. Use of } \\
\text { technology } \\
\text {. } \\
10 . \\
\text { Applicatio } \\
\text { n of } \\
\text { technology } \\
\text {. }\end{array}$ & $\begin{array}{c}\text { machines } \\
\text { are } \\
\text { currently } \\
\text { operating. } \\
\text { Common } \\
\text { tools used, } \\
\text { for the } \\
\text { realization } \\
\text { of various } \\
\text { jobs. } \\
\text { Ramps in } \\
\text { use. } \\
\text { Effective } \\
\text { use of } \\
\text { capital. }\end{array}$ & & \\
\hline $\begin{array}{l}\text { Administration: } \\
\text { For purposes of this } \\
\text { study, the } \\
\text { administrative } \\
\text { process includes the } \\
\text { administrative } \\
\text { management as are } \\
\text { the planning, } \\
\text { integration, } \\
\text { direction and } \\
\text { control headed by a } \\
\text { director capable, to } \\
\text { make the members } \\
\text { a real team, } \\
\text { obtaining as a result } \\
\text { a productivity } \\
\text { ascending. } \\
\text { Which work } \\
\text { together for the } \\
\text { realization of the } \\
\text { diagnostics, repairs } \\
\text { and maintenance. }\end{array}$ & $\begin{array}{l}\text { Knowledge } \\
\text { societies are } \\
\text { those in } \\
\text { which a large } \\
\text { part of the } \\
\text { labor force } \\
\text { has risen } \\
\text { from manual } \\
\text { labor to } \\
\text { technical } \\
\text { tasks and } \\
\text { information } \\
\text { processing } \\
\text { that require } \\
\text { education and } \\
\text { knowledge. } \\
\text { For (Heizer } \\
\text { and } \\
\text { render, 1996) } \\
\text {. The } \\
\text { administratio } \\
\mathrm{n} \text { is a factor } \\
\text { in production } \\
\text { and an } \\
\text { economic } \\
\text { resource. The } \\
\text { administratio } \\
\mathrm{n} \text { is } \\
\text { responsible } \\
\text { for ensuring } \\
\text { that labor and } \\
\text { capital are } \\
\text { used } \\
\text { effectively to }\end{array}$ & $\begin{array}{c}1 . \\
\text { Planning. } \\
2 . \\
\text { Integration } \\
. \\
3 . \\
\text { Address. } \\
4 . \text { Control. } \\
5 . \\
\text { Manager. } \\
6 . \\
\text { Advisers. } \\
7 . \\
\text { Technical. } \\
8 . \\
\text { Scrubbers. } \\
9 . \\
\text { Wizards. }\end{array}$ & $\begin{array}{c}\text { 1. Use of } \\
\text { the } \\
\text { knowledg } \\
\text { e. } \\
2 . \\
\text { Education. } \\
3 . \\
\text { Training. } \\
4 . \\
\text { Efficiency } \\
\text { in } \\
\text { administra } \\
\text { tive } \\
\text { manageme } \\
\text { nt. } \\
5 . \\
\text { Standardiz } \\
\text { ed work. } \\
\text { 6. Briefly } \\
\text { describe } \\
\text { how it } \\
\text { employs } \\
\text { administra } \\
\text { tive } \\
\text { process } \\
\text { (planning, } \\
\text { integration } \\
\text {, } \\
\text { manageme } \\
\text { nt, and } \\
\text { control) in } \\
\text { their daily } \\
\text { activities. } \\
7 . \text { Briefly } \\
\text { describe }\end{array}$ & $\begin{array}{c}\text { Do you } \\
\text { think a } \\
\text { poor } \\
\text { administrat } \\
\text { ive } \\
\text { manageme } \\
\text { nt } \\
\text { significantl } \\
\text { y impact } \\
\text { productivit } \\
\text { y within } \\
\text { the } \\
\text { concession } \\
\text { aire? }\end{array}$ & $\begin{array}{l}\text { Questionn } \\
\text { aire, } \\
\text { Likert } \\
\text { Scale. }\end{array}$ \\
\hline
\end{tabular}




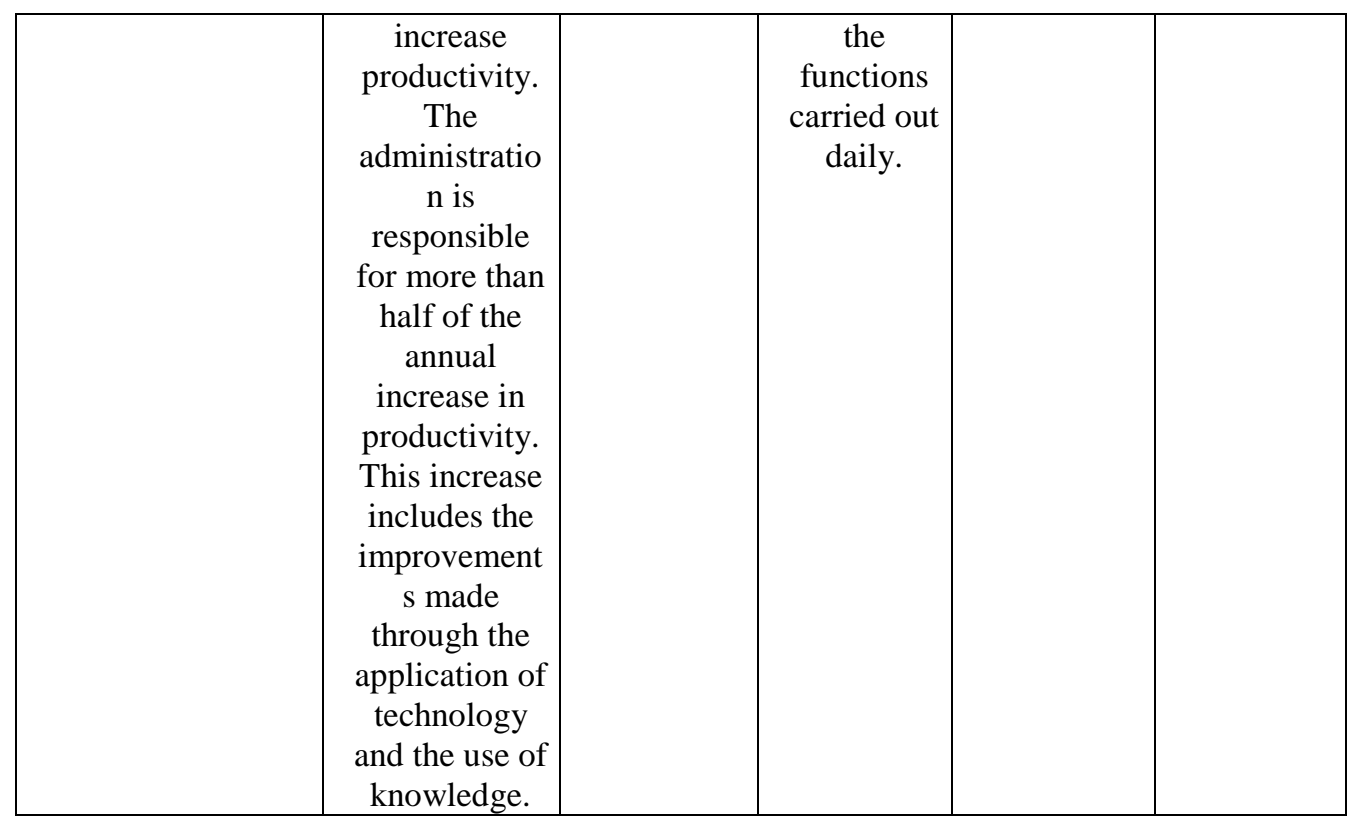

Table 1: Operationalization of variables. Source: own preparation.

Case study, such as methodological strategy

\section{What is a case study?}

The General Accounting Office of the USA United States General Accounting Office (USGAO) which has been a forerunner in the use of this methodology in the field of evaluation, presents the following definition: "A case study is a method of learning, that part of a complex example considered as a whole in its context, and is based on the understanding as a whole (holistic) from that sample, from a description and a very detailed analysis".

The case study as a strategy for research in the social sciences is "an empirical investigation of a contemporary phenomenon, taken in its context, especially when the boundaries between the phenomenon and the context are not evident" (Yin, 1994).

\section{Selection of the Research strategy}

The method of case study is a valuable tool for research, and its greatest strength lies in the fact that its measures and records the behavior of the people involved in the studied phenomenon, while quantitative methods focus on the verbal information obtained through surveys by questionnaire (Yin, 2003). In addition, the method of case study data are collected from a variety of sources, both qualitative and quantitative (Martínez, 2006). 
Table 2: demographic characteristics of the staff Honda of Playa del Carmen July 2014 (Source: Own Preparation).

\begin{tabular}{cccc}
\hline $\begin{array}{c}\text { Since Staff } \\
\text { Honda Beach } \\
\text { Carmen }\end{array}$ & $\begin{array}{c}\text { Personal Gender } \\
\text { Honda Playa del } \\
\text { Carmen }\end{array}$ & $\begin{array}{c}\text { Seniority in the } \\
\text { post } \\
\text { (Months, years) }\end{array}$ & $\begin{array}{c}\text { Seniority in the } \\
\text { automotive } \\
\text { industry (months, } \\
\text { years) }\end{array}$ \\
\hline Washer 1 & Man & 1 Year & 1 Year \\
Washer 2 & Man & 4 Years & 4 Years \\
Washer 3 & Man & 8 Months & 0 Years \\
Technician 1 & Man & 8 Years & 8 Years \\
Technical 2 & Man & 2 Years & 2 Years \\
Technical 3 & Man & 6 Years & 6 Years \\
Advisor 1 & Women & 3 Years & 3 Years \\
Advisor 2 & Women & 8 Months & 8 Years \\
Manager & Women & 1 Year & 5 Years \\
\hline
\end{tabular}

The previous table shows the demographic characteristics (gender, age in the post and seniority in the automotive industry) and the post that plays the service personnel of the concessionaire Honda Playa del Carmen (July, 2014). Resulting in its majority the masculine gender (technical and washers) and to a lesser extent the feminine gender (counselors and manager). The greater seniority in the post is headed by (technical) and the lower by ( 2 adviser and washer). With regard to seniority in the automotive industry that has more experience (technical and technical 13 ) and to a lesser extent (washer 3).

\section{Conceptualization of the productivity}

For Kast, (1993), the administration has a vital role in improving the productivity, given that acquires resources and takes investment decisions that affect the level of technology of an organization and individuals are the ones who carried out the tasks assigned to each level, from the hierarchy more high, until the lowest. According to (Adam, 1994), the productivity of the staff is remarkable through the indexes of management, through a director capable and motivating, that make the members a real team, obtaining as a result a productivity ascending. For Heizer and Render, (1996) productivity depends on three variables: Manpower, which contributes nearly $10 \%$ to the annual increase. Capital, which contributes nearly $38 \%$ annual increase and Administration, which contributes around 52\% of annual increment. These three factors are critical to increase the productivity. Represent the major areas in which administrators can act to improve the productivity 


\section{Factors of the productivity and quantification}

Productivity for Heizer and Render, (1996) is the result of dividing the outputs (goods and services) between one or more entries.

Productivity of a single factor:

Productivity= Units Produced

$$
\text { Employee Input }
$$

Total factor productivity:

$\frac{\text { Productivity Output }}{\text { Labor+ Material+ Energy+ Capital+ Other }}$

In this sense the productivity for the purpose of this research, will be measured by the offered services (maintenance, diagnostics, and repair) between the inputs (labor, capital and administration). These can be obtained through a single factor or a total factor.

According to Adam, Hershauer and Ruch, (1994), productivity is a term that describes how the conversion of inputs into outputs. Also, the defined as the ratio of the four major resource inputs of an organization.

Productivity $=\frac{\text { Products }}{\text { Labor+Capital+ Energy+ materials. }}$

Picking up what for these authors is productivity, we can say that for the purposes of this study the productivity will be measured by the services (maintenance, diagnostics, and repairs) between the labor, capital and management used to perform the services mentioned above

\section{Working hypothesis}

H1: workers believe that the training is sufficient and focused which allows them to improve the productivity.

$\mathrm{H} 2$ : the consensus of the workers is that the company has a good level of investment that can be used to improve the productivity of the service area.

H3: The workers believe that the management is the most important factor to improve productivity within the concessionaire.

\section{Georeferencing and characteristics of the object of study}

This research was conducted in the month of July 2014 in the concessionaire Honda in Playa del Carmen, Q Roo, México. The reason is that the only way for a small business to grow and increase your profitability (or profits) is increasing its productivity. And the main instrument that gives rise to a higher productivity is the use of methods that allow us to assess those factors that add or not value to the operation, in this sense the concessionaire Honda is no exception to be object of study already that accounts with the characteristics of a service provider which offers (maintenance of preventive services, diagnostics, and repair), account with 
the staff to which it is provided with facilities and tools for the realization of the services described above. Object was chosen to study the services of 5 , 10 and 20 thousand kilometers since $100 \%$ of the services offered the $80 \%$ represent preventive maintenances and the remaining $20 \%$ is divided into issues of diagnostics and repairs Honda Playa del Carmen (2014). The concessionaire Honda Playa del Carmen is located in the city of Playa del Carmen (Federal Highway Batch 39, Mz. 53, Ejido Solidarity, 77712, QR.), the kind of market is widely abroad, taking as clients to a diversity of nationalities.

\section{Description of the method of obtaining information}

The research was be confined in the modality of explanatory type, is a case study applied to Honda Playa del Carmen; to carry out the research developed a questionnaire type instrument composed of open-ended questions, and Likert scale; the technique of data collection was through personal interviews. In a first time were applied to test its effectiveness, according to the data obtained were further refined the instrument with the objective of which is accurate and meets the information needs to minimize the potential problems of interpretation.

It was subsequently applied to the total personnel of Honda Playa Del Carmen, Q Roo. To interpret data using the statistical package SPSS version 21, analyzed the results obtained and conclusions were drawn up.

\section{Source of information}

As mentioned, the information was collected with the cooperation of the management and employees of the concessionaire Honda Playa Del Carmen where we were provided with information of the company relative to their indicators, operation and functionality. It also interviewed by means of a survey of all employees in the area of service in its different levels. We applied two versions of survey to a total of 9 employees. By way of in-depth interviews this instrument was applied to the managers of the company.

\section{Statistical and graphic Method}

Perceptual Mapping is a technique of multidimensional scaling, it is a generalization of the method of principal components, where instead of having an array of observation of variables is a square matrix $\mathrm{n} \times \mathrm{n}$ of distances or dissimilarities between the $\mathrm{n}$ elements of a set (penalty, 2002). This matrix can represent the distance between the diversity of views among brands, purchase behaviors or the differences between responses from a survey or questionnaire on a particular topic, in this case the productivity, leadership, organization and employment of technology of a company, such as the example that this research represents. These distances presented here 
by perceptual mapping, are the result of a direct estimate asking opinions to employees at all levels of the concessionaire Honda of Playa del Carmen object of study in order to find dissimilarities in the views.

In terms of the multivariate statistics it has as objective or mentioned the attempt to represent this matrix using a set of variables orthogonal, called principal coordinates where $\mathrm{p}<\mathrm{n}$, so that the $\mathrm{G}$ ting en distances between the coordinates of the elements with respect to these variables are equal to or as close as possible to the distances or dissimilarities main array. That is to say, based on the matrix $D$ is intended to obtain a matrix $X$, of size $n \times p$, that can be interpreted as the array of $\mathrm{p}$ variables in the $\mathrm{n}$ individuals and where the Euclidean distance between the elements play, approximately, the distance matrix D initial. When $\mathrm{p}>2$, the variables can be sorted by importance and are typically made graphical representations in two and three dimensions such as those presented in the results of this study to understand the existing structure with the objective to describe and interpret the data.

The array of similarities although small by the number of employees of the concessionaire Honda of Playa del Carmen and therefore of the number " $n$ " of views, made it possible to represent a few variables and the structure in which the elements forming groups, have similar properties or if there are atypical elements, among other observations that are identified in the results and conclusions.

\section{Results}

\section{Spearman correlation coefficient}

The Pearson correlation coefficient measured the association between qualitative variables, takes values between -1 and +1 . The interpretation of their non-standardized values as shown below (penalty, 2002).

\begin{tabular}{|c|c|}
\hline Coefficient & Interpretation \\
\hline 0 & Null Relationship \\
\hline $0-0.2$ & Relationship very low \\
\hline $0.2-0.4$ & Low Ratio \\
\hline $0.4-0.6$ & Moderate Relationship \\
\hline $0.6-0.8$ & High Ratio \\
\hline $0.8-1$ & Relationship very high \\
\hline 1 & Perfect Relationship \\
\hline
\end{tabular}




\section{Perceptual Mapping}

Table 3: Perception by posts and correlation coefficient of the staff of Honda Playa del Carmen (washers, technicians, advisers and manager), July 2014. Source: Own Work.

\begin{tabular}{cc}
\hline Perception & $\begin{array}{c}\text { Pearson's } \\
\text { correlation } \\
\text { coefficient }\end{array}$ \\
\hline Administrative Management and its benefits on productivity & $\mathbf{0 , 0 0 5}$ \\
Years of experience in the post that plays & $\mathbf{0 , 1 7 3}$ \\
Adequacy in the training & $\mathbf{0 , 2 4 8}$ \\
Contribution of the capital in the productivity & $\mathbf{0 , 2 5 4}$ \\
Contribution of the capital invested in the productivity & $\mathbf{0 , 2 5 4}$ \\
Use of strategies to improve productivity through efficiency in the & $\mathbf{0 , 2 5 4}$ \\
use of resources & $\mathbf{0 , 2 5 4}$ \\
Capital investment to improve the productivity & $\mathbf{0 , 2 5 4}$ \\
Use and application of the technology & $\mathbf{0 , 3 8 0}$ \\
Level and frequency of training staff in the & $\mathbf{0 , 3 9 0}$ \\
Use of administrative strategies & $\mathbf{0 , 3 9 0}$ \\
According to standard performance of the concessionaire Honda & $\mathbf{0 , 8 4 8}$ \\
Knowledge of the job profile that plays & \\
\hline
\end{tabular}

This table shows the Spearman correlation coefficient, on the perception of the four variables under study (productivity, labor, capital and administration) by choosing the higher correlations and age of 1.00 with an error estimate of 0.05 and a significance level of 0.95 . It is worth mentioning that there is high correlation (association) when the correlation coefficient is between 0.7 and 1.0, medium if the correlation coefficient is between 0.05 and 0.7 and low if the ratio is between 0,000 and 0.04999 .

\section{Quality of global model (all the answers together)}

Table 4: Quality of Global Model of the almes Respect July 2014 Source: Own Work.

\begin{tabular}{ccc}
\hline Overall quality of the Model With respect to & $\begin{array}{c}\text { Value } \\
\text { in }\end{array}$ & Significance \\
\hline Overall Quality (management, capital, labor) & $J i 2$ & 1.00 \\
Administration & $J i 2$ & 0.76 \\
Capital & $J i 2$ & 0.40 \\
Labor & $J i 2$ & 0.17 \\
\hline
\end{tabular}

This table shows the overall quality of the Model studied (Honda Playa del Carmen) by measuring the relationship between the variable Post (washers, technicians, advisors, assistants and manager) and the quality of the answers given in relation to the objectives of the research in the survey to measure views. Does not represent a measurement of the variables, only sets the quality of the answers, even if the probability of positive responses were not related to the hypothesis. 
Quality of contribution model with respect to administrative management responses.

The table above show the quality of the model on the basis of the three variables in research, resulting in greater weight management, capital and labor in the same order of appearance, taking the administration 0.76, within which protrudes the perception on the profile of the post that plays with a correlation coefficient of 0.84 , which is located within the paragraph of administration. Showing exactly the opposite in terms of capital and labor, with only a 0.40 and 0.17 of quality in the responses, that is to say it is atypical to that contributed by different authors who share the view that the more capital and labor productivity would be on the rise. Represented graphically would be as follows:

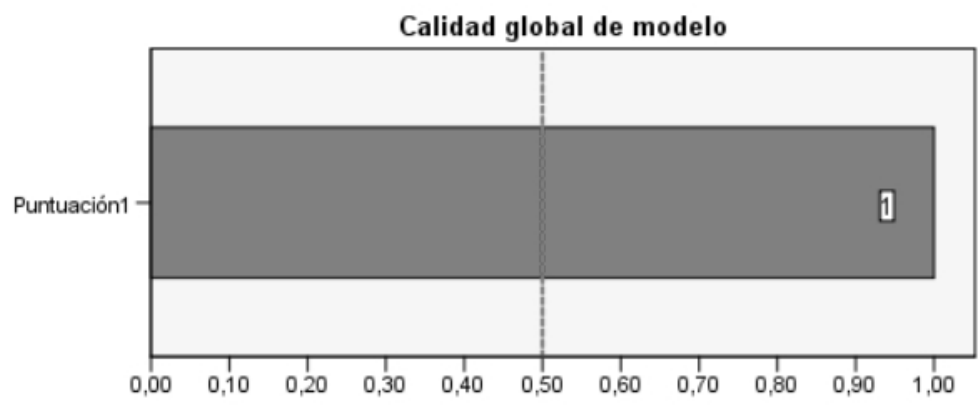

Un modelo correcto tiene un valor superior a 0,5 Un valor inferior a 0,5 indica que el modelo no es mejor que la prediccion aleatoria

Justira 1: overall quality of the model.Source: Own Preparation . 
European Journal of Contemporary Economics and Management May 2015 Edition Vol.2 No.1

ISSN: 2411-443X

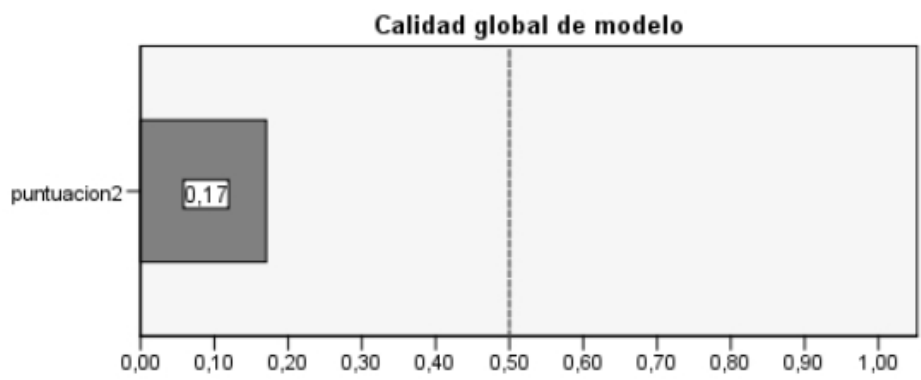

Un modelo correcto tiene un valor superior a 0,5

Un valor inferior a 0,5 indica que el modelo no es mejor que la prediccion aleatoria

Figure 2: Quality of contribution model responses with regard to labor. Source: Own Preparation.

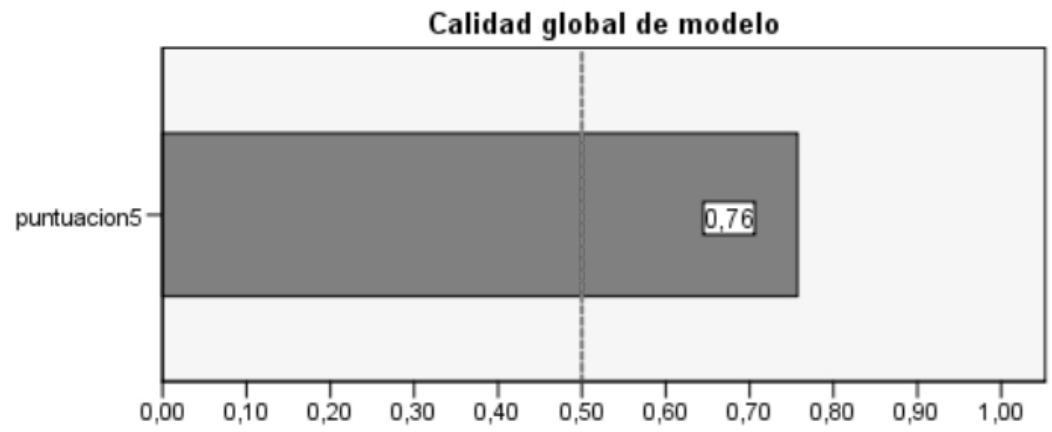

Un modelo correcto tiene un valor superior a 0,5 Un valor inferior a 0,5 indica que el modelo no es mejor que la predicción aleatoria

Figure 3: Quality of contribution model with respect to administrative management responses. Source: Own Preparation. 


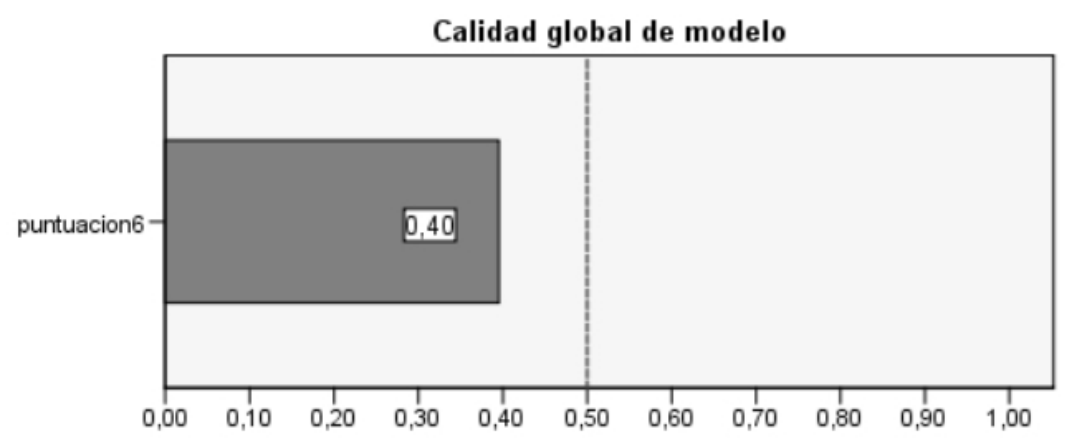

\footnotetext{
Un modelo correcto tiene un valor superior a 0,5 Un valor inferior a 0,5 indica que el modelo no es mejor que la prediccion aleatoria
}

Figure 4: Quality of model with respect to capital contribution responses. Source: Own Preparation.

\section{Findings from the analysis of intervals by Chi-squared}

With the above graphic it is clear that to understand the problem of productivity in the concessionaire Honda in study of Playa del Carmen, may explain the higher of the times the data in terms of differences in order of factors and analyzed individually by: Administrative Management, capital, and to a lesser extent by differences in quantity and quality of labor.

In a global manner, the model that includes the overall analysis of the responses of the 4 factors optimizes analysis and validates the model developed for obtaining responses (Figure 1).

\section{Results of the research}

Rojas, (2004) explains that the interpretation of results obtained in a work of research attempts to find a meaning detailed information on the ligand the knowledge obtained during the approach to the problem and the theoretical framework with the relationship of the variables belonging to the study. According to information gathered from the concessionaire automotive on the perception of the factors that affect productivity, as well as the special relationship between the labor, capital and management it is possible to carry out the interpretation of the results of the investigation.

Once obtained the results of the questionnaires of the service departments, proceeded to tabular and encode the data obtained using the statistical package SPSS, version 18, to what was used the Pearson correlation coefficient for the testing of hypotheses, by choosing the higher correlations and age of 1.00 with an error estimate of 0.05 and a significance 
level of 0.95 . Below are the results of the questionnaire. It is worth mentioning that there is high correlation (association) when the correlation coefficient is between 0.7 and 1.0, medium if the correlation coefficient is between 0.05 and 0.7 and low if the ratio is between 0,000 and 0.04999 .

With a Spearman correlation coefficient of 0,254 , it can be said that the contribution of the capital in the productivity of the staff Honda, is not significant, i.e. is not presented with the desired frequency. This is because both as technicians, advisers and managers say they lack investment, thus contributing to work better and therefore be more productive.

Within the paragraph of Administration has a Spearman correlation coefficient of 0,848 therefore we can say that the perception of the knowledge of the profile of the concessionaire Honda, is significant, that is to say that the staff Honda knows the profile of the job that plays.

According to the Spearman correlation coefficient of 0,248 (Labor, one can perceive that there is not enough training to the staff Honda, not presented association. That is to say there is not enough training for certain areas.

\section{Discussion of the Results}

In regard to Honda Playa Del Carmen.

Leontief, (1973), in its input-output model of the company based its importance in the relationship of the production function with the inputs, considering the productivity as a result of this relationship, that has to generate income that facilitate the recovery of input costs. When it focuses on the productivity exclusively the labor factor is modifying the system. Therefore the model treats all of the elements or inputs interrelated, which provides a more integrated performance or productivity.

With the above data we can see that the capital invested in the concessionaire is not presented in the same proportion and not with the desired frequency, which for Honda Playa Del Carmen would work better, be more productive.

Lawler, (1968), in his motivational model, which considers the relations existing between the preset psychological perceptions of equity, satisfaction and ability to affect the effort, with the probabilities of the effort for the performance. Constitute a normative model of individual performance.

For Honda Playa del Carmen you can perceive that there is not enough training for staff, i.e. there are no sufficient training for certain areas.

The causes of the increase in productivity for (Kast, 1993), the administration has a vital role in improving the productivity, given that acquires resources and investment decisions that affect the level of 
technology of an organization and individuals are the ones who carried out the tasks assigned to each level, from the hierarchy more high, up to the lowest. The improvement of the productivity requires an administration directly involved in the operational level. The same author, also said that" the productivity is influenced substantially by the motivation and the dedication of the people".

In the concessionaire Honda Playa Del Carmen, within the section administration we have the question about the knowledge of the profile, and the staff is very familiar with the profile of the post that plays.

In all the three variables of research (labor, capital and administration), according to (Adam, 1994) the productivity of the worker in the first place is the key to the economic viability and the accumulation of wealth, increases with the specialization and the design of the post, it is incremented when the working class works best, progresses by means of capital investment. Then, the productivity of the staff is remarkable through the indexes of management, through a director capable and motivating, that make the members a real team, obtaining as a result productivity ascending. For Heizer and Render, (1996) labor contributes almost 10\% to the annual increase, the capital approximately a $38 \%$ and the administration around the $52 \%$ to the annual increment. These three factors are critical to increase the productivity. Represent the major areas in which administrators can act to improve the productivity. And finally the American Management Association, Torres, (1997) in a survey carried out among six thousand executives of large corporations in the United States, to identify the factors that influence the productivity, defined the three more important: technology was marked by the $35 \%$ of managers, the $27 \%$ corresponded to the investment of capital and more than $20 \%$ indicated that the decisive factor was the administration.

\section{Conclusion discussion of the results}

In this sense, we can conclude that for the staff of Honda Playa Del Carmen, the Administration factor, in their points of view, is the one that contributes to a greater extent an increase in the productivity, and same way tied with the contribution of the authors as Adam, (1994) and Heizer and Render, (1996) which they expose the previously mentioned perspective.

\section{Conclusions}

This research work was carried out to the concessionaire automotive, Honda Playa Del Carmen, therefore the results, are limited to the concessionaire before mentioned and correspond to the latched on fieldwork undertaken in the month of July 2014. The study focused on the one hand, to assess the perceptions of the factors that affect the productivity in the 
workshop area of a concessionaire automotive (Honda Playa Del Carmen), and on the other hand, in the elaboration of the theoretical framework of contextual productivity and automotive industry, as well, to propose a model for measurement of productivity based on the factors (labor, capital and administration) and finally in the design of the methodological strategy to assess the perception of the above factors, in the workshop area of the concessionaire in automotive study.

To perform the research was carried out the questionnaire to open questions mode and Likert scale, which was composed of 40 questions formed in the following manner (10 productivity, 10 capital, 8 labor and 12 administration). Of which there is agreement that the administration is the most weight and participation in the productivity, this according to the service employees, but as discussed above is only the perception of the employees. Therefore this would be one of the limitations as there are many differences in the views, there is no trend. That is why it is suggested to investigate a greater number of dealerships and service personnel, perhaps in this way, we could see a thought more standard.

Let me begin by mentioning the research hypothesis which are the following:

H1: workers believe that the training is sufficient and focused which allows them to improve the productivity.

In this sense it could be said, the answers of the respondents threw diversity of opinions there are those who commented that the training is sufficient and those who commented that for the post that play there is no training. Therefore there is no significant relationship between training and productivity. That is to say with Pearson's correlation coefficient of 0,248 (low ratio), it can be said that the perception of the level of sufficient training for the staff Honda, show no association. That is to say there is not enough training for certain areas. As well as considering a Pearson correlation coefficient of 0,380 , we can say that the training of staff Honda Playa Del Carmen, is not significant, i.e. is not presented with the desired frequency. This is because both as technical manager and regularly comment that is sufficient.

$\mathrm{H} 2$ : the consensus of the workers is that the company has a good level of investment that allows improving the productivity of the service area.

In terms of capital invested the staff of service says that they are not invested significantly in technology issues, capital in general, since the comments with regard to how much has been invested in the last year, the response was the following \$25,000.00 mn Honda in Playa del Carmen, at the same time mention was made that the technology with which they have don't give you enough application use and therefore rely on an acceptable capital does not benefit as an increase in productivity. 
With a Pearson's correlation coefficient for 0,254 , we can say that the perception of the staff of the service area on the contribution of capital to the productivity of Honda Playa Del Carmen, is not significant, the ratio is low, i.e. does not have the optimal capital.

The opinion of the service staff is represented by Pearson Correlation Coefficient of 0,254, which shows us that the contribution of capital in the productivity of the staff Honda, is not significant (low ratio), i.e. is not presented with the desired frequency. This is because both as technicians, advisers and manager commented that lack investment, thus contributing to work better and therefore be more productive.

Considering the Pearson correlation coefficient of 0,254 , the personal Honda Playa Del Carmen tells us that the use and application of technology to improve the productivity of the concessionaire Honda, is not significant, i.e. is not presented with the desired frequency. This is because both as a technician and manager commented that do not use or apply or little used and applied technology.

H3: The workers believe that the management is the most important factor to improve productivity within the concessionaire.

Within the paragraph of Administration is the next Pearson's correlation coefficient for 0,848 , in this context, we can say that the perception of the knowledge of the profile of the concessionaire Honda Playa Del Carmen, is significant (very high), that is to say that the staff knows the profile of the job that plays. Which brings benefits to the variable of study (productivity).

\section{Limitations}

Within the limitations we must highlight a part, the small number of employees; and; on the other hand, the results may be influenced by the perception of each of the respondents. Future research may evaluate in greater number of employees of the service area in statesmanship concessionaires. This work could be used in combination of the various contributions of the authors treated in the same in order to provide a model to follow to increase productivity in the service area of a concessionaire automotive. Likewise, we hope that the methodology proposed to show the perception of the factors that affect the productivity of the workshop area of a concessionaire automotive is replicated to give validity in terms of consistency of the results of this research.

\section{References:}

Adam, E; Hershauer Ruch and J. W. (1997), "Productivity and quality measurement and improvement. (2ED). Mexico. Trillas. 
Asomoza, M. (1985) "Influence of the design in the labor productivity of the companies" Mexico .CICA.

Bain, D. (1997). "Productivity Solution to the problems of the Company". 2nd edition. Mexico.Editorial McGraw Hill.

Brown, P; Lauder, H and Asthon, D. (2011),"The Global Auction: The Broken Promises of Education, Jobs, and Incomes Oxford University Press, ISBN 978-0 -19-973168-8.

Bruce, K. (2006). "Henry S. Dennison, Elton Mayo, and Human Relations historiography" in: Management \& Organizational History, 1: 177-199.

Craig, C. Harris, R. (1973)" "Total Productivity Measurement at the Firm Level". Sloan Management Review (Spring 1973): 13-28.

Everett, A. (1994). "Productivity and quality". Mexico. Editorial Trillas.

Ghobadian, A. and Husbahd, T. (1990). "Measuring Total Productivity Using Productions Functions", int. J. Prod. Res., vol. 28, NO. 8.

Kast, F. and Resenzweig, J. (1993). "Administration in organizations". 4th edition Mexico, Editorial McGraw Hill.

Kast, F. and Resenzweig, J. (1995). "Managing in organizations. "Fourth edition, Mexico .Editorial Mcgraw-hill .

Leontief, W. (1986). "Input-Output Economics". 2Nded. New York, Oxford University Press.

May, E. (2004). "Critical evaluations in Business and Management".Ed. John Cunningham Wood, Michael C. Wood.

Worth, D. (2002), "Analysis of multivariate data". Mexico edit. McGraw Hill.

Plaza Automotive SA de CV "Manual of Policies and Procedures" to the original broadcast September 01 2011, as amended in January 2014.

Porter, M. (1997)" "Competitive Advantage", creation and maintenance of a Superior Performance.14th edition. Mexico, Editorial CECSA.

Porter, M. (1997),"How Much Does Industry Matter, really." Strategic Management Journal, 18 (Summer Special Issue), pp. 15-30.

Porter, M. and Lawler, E. (1968). "Managerial Attitudes and Performance". Homewood, IL: Richard D. Irwin, Inc.

Pritchard, R. (1992),"Measuring \& Improving Organizational Productivity". A Practical Guide. Praeger. United States.

Prokopenko, J. (1989)."The Productivity Management: Its process in small and medium industry". Mexico. Trillas.

Prokopenko, J. (1991)."The Productivity Management". Mexico. Editorial Noriega-Limusa .

Quesnay, F. (1758). "Tableau economique". Reprinted in Quesnay, F. (2004) The Economical Table. University Press of the Pacific.

Quesnay, F. (1766). "Analyze of the formulate arithmetique du tableau économique de la distribution des Depenses savings d'une nation 
agricole". Journal of the'agriculture, du commerce \& des finances, take II, 3eme partie, pp. 11-41.

Rojas, R. (2004),"Guide for Social Research" (40a. Ed.)" Mexico .Plaza and Valdez, Editors.

Schroeder, R. (1992),"Operations Management". Mexico. McGraw Hill.

Sumanth, D. (1990),"Productivity Management". Mexico. McGraw-Hill.

Sumanth, D. (1993). "Engineering and Management Productivity”. McGraw-Hill .Mexico.

Sutermeister, R. (1976),"People and productivity". Mexico.Editorial McGraw Hill.

Sutermeister, R. (1976),"People and Productivity”.New York. McGraw-Hill

Taylor, F. (1986). "Scientific Management". Barcelona, Spain, Editorial Orbis.

Torres, Z. (1997)."The productivity in the Micro and Small Industries of sweets and chocolates, located in Mexico City and Metropolitan Area". Doctoral dissertation. IPN-ESCA, Mexico.

Mexican Association of the Automotive Industry (2014) figures for August and accumulated 2014, Bulletin of the Press, 2014. Removed on 19 September 2014 http://www.amia.com.mx/boletin/0814.pdf

Secretariat of Economy (2012) figures of March 2012, automotive industry, monograph, Directorate General of heavy industry and high technology. Removed on

September

2014 http://www.economia.gob.mx/files/comunidad_negocios/industria_com ercio/Estudios/monografia_automotriz_marzo.pdf

Honda of Mexico. Removed on 20 October 2013 in https://www.google.com.mx/\#q=historia+de+honda+automotriz

Honda of Mexico. Removed on 20 October 2013 in http://www.honda.mx/corporativo/movilidad/

Honda of Mexico. Removed on 20 October 2013 in http://www.honda.mx/preguntas-frecuentes

http://www.scielo.cl/scielo.php?script=sci_arttext\&pid=S071909482012000 200008\&lng=es\&nrm=iso\&tlng=es 


\section{BIOS}

Francicsco Javier Güémez Ricalde is Phd in Ecology and Sustainable Development by the Colegio de la Frontera Sur. Researcher and lecturer at the University of Quintana Roo, attached to the Chair of Research Seminar I and II. Can be contacted at the University of Quintana Roo., Campus Chetumal. Boulevard Bay s/n, Esq, Ignacio Comonfort, colony of the forest, Chetumal, Zip Code 77019, Quintana Roo, Mexico.

Email: fragueme@uqroo.edu.mx; fragueme@ hotmail.com

Augustine Vilchis Vidal is a Doctor in Organizational studies by the Metropolitan Autonomous University. Associate Professor at the Universidad Autónoma de Ciudad Juárez, attached to the Chair of applied research. Can be contacted at the Institute of Social Sciences and Administration, Universidad Autónoma de Ciudad Juárez, Avenida Plutarco Elías Calles No. 1210, Cologne Foviste Chamizal, Zip Code 32310, Ciudad Juarez, Chihuahua, Mexico. Email: agustinvilchis@uacj.mx

Norma Yadira Ramos Aranda is a student in administration from the Universidad Autónoma de Ciudad Juárez. Can be contacted at the Institute of Social Sciences and Administration, Universidad Autónoma de Ciudad Juárez, Avenida Plutarco Elías Calles No. 1210, Cologne Fovissste Chamizal, Ciudad Juarez, Chihuahua, Mexico. Email: yadiramos510@ hotmail.com 